\title{
Living with Multiple Sclerosis: Perception and Coping
}

\author{
Ms. Dinika Anand ${ }^{1}$ and Dr. Rajiv Anand ${ }^{2}$ \\ ${ }^{1}$ Defence Institute of Psychological Research \\ ${ }^{2}$ Max Superspeciality Hospital
}

\begin{abstract}
Multiple Sclerosis (MS) is a traumatizing and daunting diagnosis that many people are forced to come to terms with. The unpredictable and uncertain course of the illness coupled with absence of any definitive cure makes it compelling and life changing. This article attempts to study the perceptions, conflicts and coping strategies used by patients and their family members. Using in-depth qualitative interviews with the families of two patients with MS, it was found that dealing with the loss of control with respect to one's life and future was the most painful outcome of the disease. The illness adversely affected the communication patterns in the families which gave rise to conflicts in the family unit. Lastly it was found that denial, repression, escaping, hope maintenance, positive thinking and spirituality were the dominant coping mechanisms used. The global and deep seated impact of illness in the emotional and psychological lives of individuals was highlighted.
\end{abstract}

Key Words: Multiple Sclerosis, Life Experiences, Understanding of illness, Conflicts in life, Coping.

\section{Introduction}

Multiple Sclerosis (MS) is a chronic, progressive disease which produces demyelination of the central nervous system nerve fibres resulting in disordered transmission of nerve impulses. It is thought to affect more than 2.5 million people worldwide with more women being affected than men. Symptoms vary widely and affect sensory-tactile, motor, visual, bladder, sexual, and bowel functioning. The course of MS is idiosyncratic and unpredictable, the exact causes are poorly understood, and there is no known cure. Considerable evidence exists indicating that MS has profound social and psychological consequences for both care receiver and care giver (e.g., Albuquerque, Geraldo, Martins, \& Ribeiro, 2015; Chruzander, Ytterberg, Gottberg, Einarsson, Holmqvist, \& Johansson, 2014).

MS not only changes the life of the patient drastically but also causes some forceful changes in the life of family members and relatives. The difficulties of family members are not limited to the management of the illness, its symptoms and its ramifications alone. As a family member one has to grieve and mourn the loss of vitality of not just the patient with MS but also mourn the pain of losing control of the future that they had envisioned for themselves, the person with MS and as a family. Graham's description of family caregiving as a labour of love fits this finding excellently, since it expresses the duality between the affection that is supposed to underlie the act of informal caregiving and its labour-intensive nature (Graham, 1983). The extent and nature of complications MS adds to the lives of women is perhaps far worse than its impact on the male patients. The author attempts to focus on the emotional and psychological burden of MS experienced by a patient and the family members as they cope with the illness. The aim is to try and unpackage the individual lives of a family in which there is an MS patient in order to perceive and appreciate the way MS is a part of their reality. In essence, the article attempts to understand the way family members navigate through each day of their life as they carry the burden of this illness with them.

\section{Method}

The objectives of the study were realized by conducting semi structured interviews which were intensive and primarily involved the participant narrating their views and experiences. The questions primarily acted as anchors during the interviews because each of the interviews developed and evolved dynamically. Some of the themes that were covered in the interview schedule touched upon the process of diagnosis, the process of adjusting to the symptoms, attacks, medication regimes and specific ways in which educational, professional, and familial spheres were impacted and affected by the illness. All the interviews were conducted in the home 
environment of the participants keeping in mind the comfort and ease of the participants and their family members. Given the emotionally significant nature of the topic being explored, each interview was conducted over 2-3 meetings. In addition, audio recording of the interviews was done so that the researcher can be present for the participant as well as to ensure that the finer nuances of the participant's responses can be attended to during analysis. Each meeting lasted about 60-90 minutes on an average.

\section{Results}

The aim of the present study was to explore and understand the ways in which patients and their family members respond to the eventuality of MS and the kind of patterns of coping and behaving that are exhibited by them in the context of this illness. The narratives generated from the interviews were perused over carefully to recognize and appreciate the subtle nuances of the perceptions reflected by them. Each of the interviews was thus subjected to thematic analysis in order to highlight the salient themes reflecting adjustment, coping and attitude of the individual towards the illness and its ramifications. The salient themes that emerged in the interviews are presented in Table 1 below. Overall it was found that both the families felt that accepting the illness was a gradual but necessary step in their journey. Also communication patterns were impacted in both the families due to the illness and all participants indicated that destiny and the will of God were anchors that helped them cope with the illness.

TABLE I: List of Emergent Themes

\begin{tabular}{|c|c|c|}
\hline \multirow{2}{*}{ Theme } & \multicolumn{2}{|c|}{ Supporting Statements } \\
\hline & Family $1(\mathrm{~T})$ & Family $2(\mathrm{~S})$ \\
\hline $\begin{array}{l}\text { Responding to the } \\
\text { diagnosis }\end{array}$ & $\begin{array}{l}\text { "it was little stressful, imagine you being of 20-21 of } \\
\text { age and you are practicing writing" }\end{array}$ & $\begin{array}{l}\text { "they told us that it is MS but I didn't think much of } \\
\text { it....my will power is very strong...I took the illness } \\
\text { very positively" }\end{array}$ \\
\hline $\begin{array}{l}\text { Accepting the } \\
\text { Illness }\end{array}$ & $\begin{array}{l}\text { "at the worst what will happen... her life would be this } \\
\text { much only" }\end{array}$ & $\begin{array}{l}\text { "we accepted it...I have accepted it by thinking this } \\
\text { is destiny. This is my fate" }\end{array}$ \\
\hline $\begin{array}{l}\text { Living with the } \\
\text { Illness }\end{array}$ & $\begin{array}{l}\text { "There are other problems as well, like constipation due } \\
\text { the medicines she takes that makes her irritable as well, } \\
\text { because she stops eating normally" }\end{array}$ & $\begin{array}{l}\text { "mama would have attacks but they would last for a } \\
\text { week mostly. She would get a drip also but she used } \\
\text { to do everything with me, we used to go to the } \\
\text { market also" }\end{array}$ \\
\hline $\begin{array}{l}\text { Communication } \\
\text { within the Family }\end{array}$ & $\begin{array}{l}\text { "I keep the worst to myself. Perhaps, he can't imagine } \\
\text { the worst even" } \\
\text { "No I don't share, she tries to trick me into a labyrinth } \\
\text { of questions but I find my way out" }\end{array}$ & $\begin{array}{l}\text { "I don't talk to anyone much, my friends also know } \\
\text { to not ask me anything, they understand everything. } \\
\text { I have explained to them that not to talk of this. } \\
\text { What can a person do really, just accept it as fate } \\
\text { and keep moving on quietly" }\end{array}$ \\
\hline $\begin{array}{l}\text { Coping with the } \\
\text { Illness }\end{array}$ & $\begin{array}{l}\text { "I think till date that something good will happen, but } \\
\text { what will happen or when I don't know. You see what } \\
\text { are the options?" } \\
\text { "Yes, the hectic timing is a blessing in disguise as it has } \\
\text { kept my mind away from the illness." } \\
\text { "I think the disease has impacted us for better and } \\
\text { worse. I have become atleast more closer to her and } \\
\text { maybe have earned her trust as well." }\end{array}$ & $\begin{array}{l}\text { "the impact on their life is much worse because their } \\
\text { lives have changed completely....now my } \\
\text { understanding level has increased a lot...I can take } \\
\text { in what their state is also... at first my ego had } \\
\text { become too strong and I used to only think that they } \\
\text { are doing nothing in my pain, they are all doing their } \\
\text { own things and leaving me...today I know that they } \\
\text { have a right to go out...now I only push them that } \\
\text { they should go and not worry about me" } \\
\text { "a friend of mine showed me a picture of a guru, I }\end{array}$ \\
\hline $\begin{array}{l}\text { Spirituality as an } \\
\text { anchor }\end{array}$ & $\begin{array}{l}\text { "Before I didn't use to go to the temple regularly but } \\
\text { now I make it a point to go the temple daily also I feel } \\
\text { while praying it's my time of peace. Also, I feel that } \\
\text { somewhere, some blessings will come out of } \\
\text { it..something positive" }\end{array}$ & $\begin{array}{l}\text { started crying on seeing the picture...my tears just } \\
\text { would not stop. I told her that I had perhaps met } \\
\text { him, she took me to his temple. He helped me get } \\
\text { peace, change and find a reason to live. He cured me } \\
\text { of my fears. I have become a happy person because } \\
\text { of him" }\end{array}$ \\
\hline $\begin{array}{l}\text { The Life Courses } \\
\text { Altered by the } \\
\text { Illness }\end{array}$ & $\begin{array}{l}\text { "At first I thought of doing } \mathrm{PhD} \text {, but then after MS...I } \\
\text { thought that I won't do my } \mathrm{PhD} \text { and now I am stuck in } \\
\text { a job with which I am not happy and nobody would like } \\
\text { me sitting at home without a job so I am stuck with my } \\
\text { job....I don't have options" }\end{array}$ & $\begin{array}{l}\text { "where there is illness, normalcy is not } \\
\text { possible....nothing stays same in the family" } \\
\text { "it has indeed affected the children, they became } \\
\text { mature very soon, one has to make a lot of } \\
\text { adjustments....I had to give my daughter the car at } \\
15 \text { " }\end{array}$ \\
\hline $\begin{array}{l}\text { Thoughts about the } \\
\text { Future }\end{array}$ & $\begin{array}{l}\text { "well about tomorrow, I know that my disease will take } \\
\text { over eventually it has to still I won't think about } \\
\text { tomorrow because even the thought scares me" }\end{array}$ & $\begin{array}{l}\text { "no } 20 \text { year old girl worries about or thinks about } \\
\text { her own wedding, but I worry about it all....but then } \\
\text { I tell myself that there is a lot of time for it at the } \\
\text { moment" }\end{array}$ \\
\hline
\end{tabular}




\section{Discussion}

The aim of the present study was to develop an understanding of the perceptions, conflicts and coping strategies of patients with Multiple Sclerosis (MS) and their family members. This discussion attempts to piece together the narratives of the participants and obtain an understanding of the intricacies and nuances of their lives so as to enable the reader to appreciate and recognize the actual presence of the disease in their lives. Literature points that the diagnosis of MS is often met with shock, grief, anger, despair and a sense of hopelessness in patients and their family members because of the debilitating nature of the illness. In the present study the participants responded to the diagnosis with a mixture of shock, grief and hope. Both the families reported that they did not think that the worst of the disease will be a part of their lives.

The diagnosis of MS essentially threatens our perceived sense of control over our lives and future due to its unpredictable and variable course (Mohr \& Dick, 1998; Geronemus, 1980). In this context, optimistic thinking is essentially an attempt to maintain a sense of power and control over the illness and life. The participants conformed to these finding to the extent that both families had not accepted the diagnosis to be final and made consistent attempts to seek out new treatments, therapies and drugs that were said to benefit patients with MS.

The participants felt that acceptance of the illness as a part of life is a forced implication of the increasing severity of the disease and the associated disability. It is critical to note that truly accepting the disease essentially demands that one has to recognize and acknowledge a sense of powerlessness so acute that they cannot be sure whether they will be able to flex their fingers tomorrow or not. In case of both the families, the experience of absence of choice and the power to make decisions was reported by all the members in reference to the process of accepting, a facet highlighted in literature also (Boeijea et al., 2004). A potent illustration of this need is seen in participant \# 2's narrative of instances wherein she refused to rest despite being sick or shouldering all the responsibilities that a wife, daughter in law and mother was expected to do despite the fact that the repeated attacks incapacitated her. The strongest example is seen in her refusal to address to the pain in her leg at the time she fractured it and attending to the injury in her leg only after she had spent her day as planned.

Accepting the illness along with its ramifications would mean acknowledging the loss of not just one's power over the today but also admitting that every single image they had created in their minds about the future was now shattered and destroyed. The stress of this process is almost impossible to capture and words like hopelessness, despair, pain, grief, fear, anger and frustration are at best inadequate. Needless to say, individuals try to forestall this agony as far as possible and thus do not accept the worst of the illness as a part of their lives till the illness forces them to.

However, the researcher feels that even as these attempts point to certain disconnect with the reality of the illness yet this behavior might actually be beneficial at some level. As represented by the participants, their conditional acceptance was the driving force that allowed them to maintain a sense of normalcy and continue pursuing of their planned life goals. T's father was able to infuse a sense of hope in his wife and help her deal with the grief of the diagnosis because he accepted the illness only with the condition that he will not lose hope and will always look out for the positive aspects of the situation. This behavior finds support in research which found that hope facilitates coping with the concomitant stressors of physical illness and leads to better adjustment and adaptation. Also, it helps people to stay energized and focused on their goals and their wish for recuperation (Barnum et al., 1998; Hamilton \& Ingram, 2001).

The impact of the illness on relationships and communication patterns within the family was also explored in this study. In case of participant \# 1, there was a perception that T's father had not accepted the illness and thus there were some conflicts between $\mathrm{T}$ and him. These conflicts were perhaps fostered by the fact that apart from $\mathrm{T}$ who shared her frustrations and thoughts with her brother, the whole family did not communicate openly with each other. Both the parents tried to shield each other from the knowledge that they had thought about the worst possible implication of the illness and hence carried the burden of their fears and anxieties alone. Due to this $\mathrm{T}$ believed that her father did not accept the consequences of the diagnosis and hence pushed her beyond her capacities and often felt that he tried to deny the reality. However, her father shared that his emphasis on positive thinking was to driven by a desire to better equip $\mathrm{T}$ to deal with the illness.

T's responses about the difficulty of accepting the illness and her family's reports about her recent depressive phase perhaps bear testimony to the fact that she was thinking, perceiving and acknowledging the 
illness only now when it forced her to be absent from her job repeatedly and for long durations. It is felt that being forced to accept the illness because of the frequent attacks in the past year had made $\mathrm{T}$ acutely aware and conscious of the predicament of the illness. She was perhaps going through a phase wherein she was striving to reconfigure her daily life in order to include the illness in her daily lives and identity, an aspect discussed by Olsson, Lexell, \& Söderberg as well (Olsson, Lexell, \& Söderberg, 2008). Her behavior reflected attempts to bring the illness out in the open spaces of the family and attribute a lot of ordinary daily life events and hassles to the illness. This behavior was found to be in support of research findings discussed in the preceding pages that highlight the role of illness identity and illness representations in the way people respond and adjust to the illness (Leventhal, Nerenz, \& Steele, 1984).

This lack of communication amongst the family members was perhaps responsible for T's parents reporting that they felt light hearted and comfortable about the sharing they had done. The fact that $\mathrm{T}$ often had to seek her brother's intervention in order to communicate her perspective to her parents also points to the need for better communication channels within the family. The responses of participant \# 2 and her daughter bespoke of potent feelings of anger, disappointment, hurt and accusation which hinted of strained relationships and blocked communication channels. All 3 members had developed coping strategies at an individual level and the family unit along with the son suffered because of it. Each of them was unhappy about some aspect of the other people's behavior and hence each of them had lost hope and faith in the family unit.

Another factor which was observed was that both the participants did not seek social support or the help of outsiders in order to better adjust to the illness. In both cases, the need to find help and support outside the family was blatantly rejected by both T's father and S's husband. They communicated a sense that outsiders are not capable of helping them in any way and thus they kept the illness and their thoughts and feelings to themselves. However, T's mother's comments about the need to share information about the illness with at least the extended family and the contrasting needs of her husband as well as participant \# 2's husband to confine the illness within the family can be explained with the help of McCabea et al.'s research which points that perception of lack of control over the illness may lead respondents to feel helpless and depressed. Thus, while both the patients and the mother of participant 1 reached out to others in helping them cope, T's father and S's husband both tried to avoid that feeling of having no control over the illness and maintained a task focused solution centric approach to deal with the disease (McCabea, McKerna, \& McDonald, 2004).

The coping processes of patients and their family members formed a critical part of this research. The task of coping with an illness like MS is specially challenging because of the nature of the illness. The eventual reality of losing control over one's bodily function to the extent that one's existence is almost vegetative is the baggage one has to carry while coping with MS. The family members of patients are essentially caught in a web of complexities and difficulties wherein the added responsibilities of managing the household, taking over the responsibilities and functions of the person with MS, dealing with the attacks and subsequent hospital visits and so on are significant sources of stress apart from the grief and pain they suffer because of the grave nature of the diagnosis. The coping strategies of the participants were found to lie either along the dimensions of an active acceptance and appreciation of the disease and the impact it can have on the life of the patient at one end and along dimensions of a conditional or partial acceptance of the illness at the other end. The complexity of the situation in which each of the participants was placed prevents the researcher from pin pointing any one strategy as appropriate or inappropriate. Also, even as the responses indicated a firm bent towards conditional or unconditional acceptance of the illness yet there were parts in the narratives of each participant where they were found to veer towards the other end.

The benefit of coping strategies that are based on an appraisal of reality and are in tune with the current situational factors is highlighted in literature time and again. Relying on techniques like problem solving, positive reappraisal, positive reappraisal and benefit finding is said to be reflective of effective coping (Davis et al., 1998; Dennison et al., 2009). In the study, elements of denial, repression and escapism were found in the coping processes employed by participant \# 1's father and brother and participant \# 2's husband and daughter. Participant \# 2's daughter and participant \# 1 appeared to use a mix of resignation, escapism and acceptance to cope with the illness as indicated by their responses. As discussed above, participant \# 1 was perhaps going through a phase where she was still grappling with the diagnosis and thus a definite comment on her coping styles in not possible. In case of the daughter of participant \# 2, the sense of powerlessness experienced by her was perhaps acute because she did not perhaps get a fair chance to develop a coping style based on her own 
understanding of the situation. This realization comes from the fact that the coping styles of her parents appeared to be complimentary and reactionary to each other and thus gave them both the space to experience and express their thoughts and feelings; while she was left with the task of making sense of their positions and creating a position of her own. Perhaps this lack of space was because in the eyes of her parents she was a child and hence her individuality and unique perspective was not given the importance it was worthy of.

The responses of participant \# 2 indicated that she had now accepted the illness and coped with her difficulties by relying on spirituality and God. The use of God and spirituality as an anchor was seen in other respondents also; specifically T's mother who employed it as a critical anchor. Their behavior finds support in the work of Pargament and his colleagues (Pargament, 1997; Pargament, et al., 1988) who have found that under highly stressful life events, including physical ill health, positive religious ways of coping, such as seeking spiritual support and connection, and the use of collaborative religious coping are related to better quality of life and lower levels of depression, anxiety, and anger.

A significant factor in understanding the coping processes of participant \# 2's husband may be found in the concept of illness intrusiveness as defined by Devins in his work. The concept refers to illness-induced lifestyle disruptions that interfere with continued involvements in valued activities and interests (Devins et al., 1993; Devins et al., 1993). The author contends that intrusiveness compromises psychosocial wellbeing and contributes to increased emotional distress through two complementary pathways: (1) reduced availability of positive life experiences, and (2) compromised feelings of personal control (Devins et al., 1993). The respondent reported the changes in his personal lifestyle as well as the inability to do anything to reclaim his desired lifestyle in the face of current life circumstances.

Overall, the researcher felt that the coping strategies adopted by individuals in such a situation cannot be written off as negative or unhealthy easily because of the very nature of the disease; one cannot question the patient for clinging on to the hope of a cure or regaining control over their lives because it is plausible that these thoughts are perhaps the only thread by which the affected people are able to face the world. False hopes, searching for small positives in the circumstances and deliberately attending to only those aspects which tell that we are better off than others are perhaps only ways through which patients can cope.

Lastly, it is imperative to note that the paper endeavors to create space for a more comprehensive, in depth and exhaustive dialogue for documenting, understanding and addressing the experiences and lived realities of patients and their caregivers. A larger, more comprehensive and representative sample that brings to focus the life stories of not just men with MS but also cuts across boundaries of socio-economic status, geographical areas will perhaps add to the depth of information obtained. At the other end, different methodological approaches will also be beneficial in adding meaning to the thinking process initiated by this work.

\section{Conclusion}

The aim of the current study was to study the experience of living with Multiple Sclerosis from the perspective of patients and their family members. An attempt was made to highlight the perceptions, conflicts and coping strategies which individuals and their family members employed as they negotiated with life in the context created by the illness. The objectives of the research were realized by conducting in-depth interviews with two female patients of Multiple Sclerosis and their family members. The results revealed that the coping strategies employed by each member were mediated by their personal understanding the disease and its implications along the understanding and attitudes reflected by other members. The responses, attitudes, understandings and coping mechanisms of all family members were found to be interwoven together and yet distinct. The global impact of the disease in the lives of the patients and each of the family members was highlighted.

\section{References}

[1] Albuquerque, C., Geraldo, A., Martins, R., \& Ribeiro, O. (2015). Quality of Life of People with Multiple Sclerosis: Clinical and Psychosocial Determinants. Procedia Social and Behavioural Sciences, 171, 359-365.

http://dx.doi.org/10.1016/j.sbspro.2015.01.133

[2] Barnum, D. D., Snyder, C., Rapoff, M. A., Mani, M. M., \& Thompson, R. (1998). Hope and Social Support in Psychological Adjustment of Children who have Survived Burn Injuries and their Matched Controls. Children's Health Care, 27 (1), 15-30. 
http://dx.doi.org/10.1207/s15326888chc2701_2

[3] Boeijea, H. R., Cecile, A., \& Janssens, J. (2004). 'It might happen or it might not': how patients with multiple sclerosis explain their perception of prognostic risk. Social Science \& Medicine, 59, 861-868.

http://dx.doi.org/10.1016/j.socscimed.2003.11.040

[4] Chruzander, C., Ytterberg, C., Gottberg, K., Einarsson, U., Holmqvist, L. W., \& Johansson, S. (2014). A 10-year follow-up of a population-based study of people with multiple sclerosis in Stockholm, Sweden: Changes in healthrelated quality of life and the value of different factors in predicting health-related quality of life. Journal of the Neurological Sciences, 339, 57-63.

http://dx.doi.org/10.1016/j.jns.2014.01.020

[5] Davis, C. M., Yarber, W. L., Bauserman, R., Schreer, G., \& Davis, S. L. (1998). Handbook of sexuality-related measures. Thousand Oaks: Sage Publications.

[6] Dennison, L., Moss-Morris, R., \& Chalder, T. (2009). A review of psychological correlates of adjustment in patients with multiple sclerosis. Clinical Psychology Review, 29, 141-153.

http://dx.doi.org/10.1016/j.cpr.2008.12.001

[7] Devins, G., \& Seland, T. (1987). Emotional impact of multiple sclerosis: recent findings and suggestions for future research. Psychological Bulletin, 101, 363-375.

http://dx.doi.org/10.1037/0033-2909.101.3.363

[8] Devins, G., Edworthy, S., Paul, L., Mandin, H., Seland, T., \& KIein, G. (1993). Differences in illness intrusiveness across rheumatoid arthritis, end-stage renal disease, and multiple sclerosis. The Journal of Nervous and Mental Disease, 181, 377-381.

http://dx.doi.org/10.1097/00005053-199306000-00007

[9] Devins, G., Edworthy, S., Paul, L., Mandin, H., Seland, T., KIein, G., et al. (1993). Restless sleep, illness intrusiveness, and depressive symptoms in three chronic illness conditions: rheumatoid arthritis, end-stage renal disease, and multiple sclerosis. Journal of Psychosomatic Research, 37, 163-170.

http://dx.doi.org/10.1016/0022-3999(93)90083-R

[10] Geronemus, D. F. (1980). The Role of the Social Worker in the Comprehensive Long Term Care of Multiple Sclerosis Patients. Neurology, 30 (2), 48-54.

http://dx.doi.org/10.1212/WNL.30.7_Part_2.48

[11] Graham, H. (1983). Caring: a labour of love. In J. Finch, \& D.Groves (Eds.), A Labour of Love: women, work and caring (pp. 13-30). Londo: Routledge \& Kegan Paul.

[12] Hamilton, N. A., \& Ingram, R. E. (2001). Self Focused Attention and Coping: Attending to the Right Things. In C. Snyder (Ed.), Coping with Stress: Effective People and Processes (pp. 178-95). New York: Oxford University Press.

[13] Leventhal, H., Nerenz, D., \& Steele, D. (1984). Illness representations and coping with health threats. In A. Baum, \& J. Singer (Eds.), A Handbook of Psychology \& Health (pp. 219-252). Hillsdale (New Jersey).

[14] McCabea, M. P., McKerna, S., \& McDonald, E. (2004). Coping and psychological adjustment among people with multiple sclerosis. Journal of Psychosomatic Research, 56, 355-361.

http://dx.doi.org/10.1016/S0022-3999(03)00132-6

[15] Mohr, D., \& Dick, L. (1998). Multiple Sclerosis. In P. Camic, \& S. Knight (Eds.), Clinical Handbook of Health Psychology: A practical guide to effective interventions (pp. 313-348). Seattle, WA: Hogrefe \& Huber.

http://dx.doi.org/10.1177/135245859800400605 http://dx.doi.org/10.1191/135245898678845160

[16] Olsson, M., Lexell, J., \& Söderberg, S. (2008). The Meaning of Women's Experiences of Living With Multiple Sclerosis. Health Care for Women International, 29 (4), 416-430. http://dx.doi.org/10.1080/07399330701876646

[17] Pargament, K. (1997). The Psychology of religion and coping: Theory, research, and practice. New York: Guilford Press.

[18] Pargament, K., Kendell, J., Hathaway, W., Gravengoed, N., Newman, J., \& Jones, W. (1988). Religion and the problem-solving process: Three styles of coping. . Journal for the Scientific Study of Religion, 27, 90-104.

http://dx.doi.org/10.2307/1387404 